\title{
COMPARATIVE STUDY OF THE QUALITY OF RASOMALAI MANUFACTURED FROM COW AND BUFFALO MILK
}

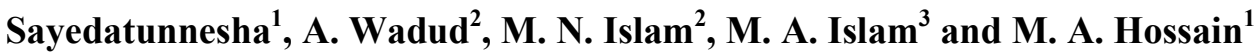

\begin{abstract}
The experiment was conducted to compare the quality of rasomalai manufactured from cow milk and buffalo milk, two types of rasomalai were prepared named as- A (cow milk) and B (buffalo milk). The qualities of prepared rasomalai were evaluated physically, chemically and microbiologically. It was found that flavor, body and texture, color and appearance and total score of A and B type samples differed significantly $(\mathrm{P}<0.01)$ and taste score non-significantly $(\mathrm{P}>0.05)$. The total solids, protein, fat, ash and carbohydrate content of $\mathrm{A}$ and $\mathrm{B}$ were $461.10 \pm 6.45$ and $540.17 \pm 3.77 ; 61.67 \pm 1.20$ and $84.00 \pm 1.15 ; 75.33 \pm 3.18$ and $125.67 \pm 3.48$; $9.13 \pm 0.09$ and $12.50 \pm 0.12$ and $314.97 \pm 4.53$ and $318.00 \pm 1.53 \mathrm{~g} / \mathrm{kg}$, respectively. All of them varied significantly $(\mathrm{P}<0.01)$ except carbohydrate $(\mathrm{P}>0.05)$. The acidity of $\alpha$ and $\beta$ were $0.21 \pm 0.00$ and $0.19 \pm 0.003$ per cent, respectively and showed significant difference $(\mathrm{P}<0.01)$. Total viable count of $\mathrm{A}$ and $\mathrm{B}$ type samples were non-significantly $(\mathrm{P}>0.05)$ different and the values were $3.84 \pm 0.05$ and $3.77 \pm 0.07 \mathrm{log} \mathrm{cfu} / \mathrm{g}$. The Coliform was absent both in A and B type sample. Buffalo milk rasomalai earns extra profit of $\mathrm{Tk}$. $35 / \mathrm{kg}$ than the cow milk rasomalai. Physical examination revealed that type A was better than type B but the chemical and microbiological findings and also the pricing of rasomalai showed that buffalo milk rasomalai was superior to cow milk rasomalai.
\end{abstract}

Key Words : Rasomalai, Cow milk, Buffalo milk, Quality

\section{Introduction}

From nutritional point of view milk is not only the most important food for newborn but also for adolescents, adults, invalids, convalescents and patients. But in this era of industrialization, food habit of common people is changing. Hence, milk is converted to various milk products. In India, out of total milk production, $40 \%$ of milk is used for the manufacture of indigenous milk products and about $4 \%$ milk is converted into chhana (Mathur et al., 1991). About $10 \%$ of the total milk produced in Bangladesh are used for the preparation of chhana and finally for sweetmeat making (Forth Plan Study, 1968). Sweetmeats have a significant role in our culture. There is no such ceremony and festival, which goes without sweetmeats. Any kind of party and guest entertainment either domestic or national level, everywhere sweetmeats are inevitable (Kuila et al., 2000). The available sweetmeats in the markets of Bangladesh are rasomalai, rasogolla, chamcham, malaikari, kalojam, sandesh, kachagolla, rasokadam, peda, rajvog, amirti, chhanar polao, monda, pantoa etc. Out of different types

\footnotetext{
${ }^{1}$ Department of Dairy Science, Bangladesh Agricultural University, Mymensingh-2202, Bangladesh

2 Professor, Department of Dairy Science, Bangladesh Agricultural University, Mymensingh-2202, Bangladesh

${ }^{3}$ Lecturer, Department of Dairy Science, Bangladesh Agricultural University, Mymensingh-2202, Bangladesh
}

(Received : July 23, 2008) 
Bang. J. Anim. Sci. 2008, 37 (1)

of sweetmeats, rasomalai is one of the most popular one (Islam et al., 2003). Some areas of Bangladesh are specially famous for some sweetmeats e.g. Muktagachha (Mymensingh district) for 'Monda,' Porabari (Tangail district) for 'Chamcham', Natore district for 'Kachagolla' and Comilla District for 'Rasomalai'. Actually where and how rasomalai was first prepared in this country is not yet known. Generally, rasomalai is made from cow milk, but the quantity of cow milk is not satisfactory round the year in our country. After cow, buffaloes are the largest source of milk supply in the world. In our country total milk production from cow and buffaloes were 7,82,000 and 24,000 MT respectively (FAO, 1997). Buffalo milk contains two times more milk fat and total solids than the cow's milk. Buffalo milk fat has less cholesterol and more tocopherol, which is a natural anti-oxidant (Personal communication). Buffalo milk contains more calcium and phosphorus and less sodium and potassium than cow's milk. So, there is a great scope of preparing rasomalai from buffalo milk. But no effort has been made to utilize buffalo milk for the preparation of rasomalai. So, the present study was carried out to monitor the quality of rasomalai made from buffalo milk, to make a comparison between the quality of rasomalai made from cow and buffalo milk and to assess the overall feasibility of making rasomalai from buffalo milk.

\section{Materials and Methods}

\section{Preparation of rasomalai}

This experiment was conducted at the Dairy Chemistry and Technology Laboratory and Dairy Microbiology Laboratory, Department of Dairy Science, Bangladesh Agricultural University, Mymensingh. Cow milk (4.10\% fat and $8.21 \%$ SNF) and buffalo milk $(8.20 \%$ fat and $9.52 \%$ SNF) were collected from the Bangladesh Agricultural University Dairy Farm. Both the cow milk and buffalo milk were divided in two portion for making chhana ball and malai. For preparing ball - the milk was heated to boil and then the temperature of milk was decreased to about $80^{\circ} \mathrm{C}$. After that, whey water was added to milk and kept it for sometimes for the separation of chhana (mainly casein) and finally, the chhana was collected by filtering it through the mouslin cloth. Then, $1 \%(\mathrm{w} / \mathrm{w})$ flour was added to the chhana and it was grinded and kneaded to prepare the chhana ball. The ball was cooked in the sugar syrup (sugar : water $=1.5: 1$ ) for 20-30 minutes. Malai was prepared by reducing the milk volume by heating to $60 \%$ for buffalo milk and $50 \%$ for cow milk with the addition of $0.4 \%$ cardamom and $2 \%$ sugar. Then the cooked chhana ball was boiled in this malai for 5 minutes. After keeping it at room temperature for 5-6 hrs., it becomes ready to serve.

\section{Analysis of the sample}

Rasomalai made from cow milk (A) and buffalo milk (B) were judged by a panel of experienced judges for physical quality by using a 100 point score card consists of flavor (45), body and texture (30), color and appearance (15) and taste (10). The total solids was obtained by oven drying, ash by incineration, fat by Babcock fat test, protein by kjeldahl, sugar by calculation, acidity by titration against $0.1(\mathrm{~N}) \mathrm{NaOH}$, total viable count by SPC agar and coliform by VRB agar method.

\section{Statistical analysis}

The design of the study was Completely Randomized Design (CRD) and analytical computer package was Mstat Programme. 


\section{Results and Discussion}

\section{Flavor}

The average flavor score of $\mathrm{A}$ and $\mathrm{B}$ type rasomalai was $43.18 \pm 0.27$ and $41.10 \pm 0.13$, respectively (Table 1) that differs significantly $(\mathrm{P}<0.01)$. Flavor score of other dairy products made from buffalo milk were lower than the products made from cow milk, like- dahi and rasogolla reported by Alam (1999); Haque (2000), respectively. This may be due to the variation in the volatile constituents of milk of different species as Marsili (2003) reported that the volatile constituents in milk make the strongest contribution to its aroma and flavor.

Table 1. Physical quality of rasomalai made from cow and buffalo milk

\begin{tabular}{|l|c|c|c|}
\hline \multirow{2}{*}{\multicolumn{1}{|c|}{ Parameters }} & \multicolumn{2}{c|}{ Type of rasomalai } & \multirow{2}{*}{ Level of significance } \\
\cline { 2 - 3 } & A & B & $* *$ \\
Flavor (45) & $43.18 \pm 0.27$ & $41.10 \pm 0.13$ & $* *$ \\
Body and texture (30) & $28.63 \pm 0.16$ & $26.57 \pm 0.29$ & $* *$ \\
Color and appearance (15) & $14.32 \pm 0.33$ & $12.74 \pm 0.06$ & NS \\
Taste (10) & $9.20 \pm 0.05$ & $8.44 \pm 0.47$ & $* *$ \\
Total score (100) & $95.33 \pm 0.75$ & $88.85 \pm 0.46$ & \\
\hline
\end{tabular}

Figure in parenthesis indicate total point

${ }^{\mathrm{NS}}$ Non significant, ** Significant at $1 \%$ level

\section{Body and texture}

Body and texture score of A and B type rasomalai differ significantly ( $\mathrm{P}<0.01$ : Table 1$)$. Higher body and texture score was recorded for A type rasomalai than B. Higher body and texture score indicates the soft and spongy body where as the lower score indicates coarse body of prepared chhana balls. In an experiment Joshi et al. (1991) reported that chhana prepared from buffalo milk had hard body and coarse texture than chhana prepared from cow milk and goat milk. Body and texture score decreased in rasogolla (small balls) with increased level of buffalo milk (De and Ray, 1954).

\section{Color and appearance}

The color and appearance score of A and B type rasomalai were $14.32 \pm 0.33$ and $12.74 \pm 0.06$, respectively (Table 1). Statistical analysis showed that there was a significant difference $(\mathrm{P}<0.01)$ between them. This variation may be due to the variation in carotene content of milk. Jainudeen (2003) stated that the buffalo converts the yellow pigments $\beta$-carotene into Vitamin A, which is colorless, and is passed into the milk. Therefore, buffalo milk is distinctively whiter than cow's milk; the latter is not only pale creamish-yellow but also the milk fat is golden yellow.

\section{Taste}

The average taste score of A and B type rasomalai was $9.20 \pm 0.05$ and $8.44 \pm 0.47$, respectively (Table 1). There was a non-significant $(\mathrm{P}>0.05)$ difference between them. Although the slight difference in taste score of two types of rasomalai were observed but both samples had acceptable pleasant taste. 
Bang. J. Anim. Sci. 2008, 37 (1)

\section{Total score}

Total physical score of A and B type of rasomalai was $95.33 \pm 0.75$ and $88.85 \pm 0.46$, respectively. As average scores for all the physical parameters of A were higher than B, the total score was also higher in A. And this higher value indicates that rasomalai manufactured from cow milk was superior to buffalo milk rasomalai. Statistical difference between the total score of A and B type samples were also significant $(\mathrm{P}<0.01)$

\section{Chemical parameters}

\section{Total solids}

The total solids content of rasomalai A and B type were $461.10 \pm 6.45$ and $540.17 \pm 3.77 \mathrm{~g} / \mathrm{kg}$, respectively (Table 2$)$. Total solids content of rasomalai samples differed significantly $(\mathrm{P}<0.01)$. The variation in total solids content was due to the variation in the milk quality.

\section{Protein}

The average protein content of A and B type rasomalai varied significantly $(\mathrm{P}<0.01)$ with the average $61.67 \pm 1.20$ and $84.00 \pm 1.15 \mathrm{~g} / \mathrm{kg}$, respectively. From Table 2, it was found that the use of buffalo milk chhana and malai enhanced the protein content of rasomalai. Because buffalo milk contains higher amount of protein than cow milk. Protein content of rasomalai was analyzed by Islam et al. (2003) and found that protein content of Milk Vita rasomalai was 8.29 per cent .On the other hand Yasmin et al. (2005) reported that protein content of laboratory made cow milk rasomalai was 17.30 per cent.

\section{Fat}

The average fat content of rasomalai $\mathrm{A}$ and $\mathrm{B}$ differ significantly $(\mathrm{P}<0.01)$. Table 2 showed that sample B $(125.67 \pm 3.48 \mathrm{~g} / \mathrm{kg})$ had the higher fat content than sample A $(75.33 \pm 3.18 \mathrm{~g} / \mathrm{kg})$ because buffalo milk contains more fat than cow's milk. Islam et al. (2003) reported that fat content of Milk Vita produced rasomalai was $7.90 \%$ and in another experiment, Yasmin et al. (2005) reported that fat content of laboratory made cow milk rasomalai was $8.00 \%$.

\section{Ash}

Significant difference $(\mathrm{P}<0.01)$ was found between the ash content of A $(9.13 \pm 0.09 \mathrm{~g} / \mathrm{kg})$ and B $(12.50 \pm 0.12 \mathrm{~g} / \mathrm{kg})$ type rasomalai. In an experiment, Katra and Bhargava (1990) reported that higher ash and total carbohydrate decreased the sponginess of the product. So, it can be said that type A was better than type B.

\section{Carbohydrate}

The amount of carbohydrate of $\mathrm{A}$ and $\mathrm{B}$ was $314.97 \pm 4.53$ and $318.00 \pm 1.53 \mathrm{~g} / \mathrm{kg}$, respectively (Table 2). There was a non-significant $(\mathrm{P}>0.05)$ difference in carbohydrate content between the samples. Because carbohydrate content of rasomalai sample depends upon the addition of sugar and starchy materials and being soluble in water, lactose in milk drained out with whey water. In this experiment same amount of sugar and flour was used for both samples and cow and buffalo milk contains more or less same amount of carbohydrate.

\section{Acidity}

It was found that the average acidity for A and B was $0.21 \pm 0.00$ and $0.19 \pm 0.003 \%$, respectively that differed significantly $(\mathrm{P}<0.01)$. From the result it was observed that the acidity decreased due to the 
use of buffalo milk for rasomalai preparation as because chhana obtained from cow milk carried higher acidities than chhana obtained from buffalo milk (Rao et al., 1989).

Table 2. Chemical and microbiological quality of rasomalai made from cow and buffalo milk

\begin{tabular}{|c|c|c|c|}
\hline \multirow{2}{*}{ Parameters } & \multicolumn{2}{|c|}{ Types of rasomalai } & \multirow{2}{*}{ Level of significance } \\
\hline & A & B & \\
\hline \multicolumn{4}{|l|}{ Chemical } \\
\hline Total solids (g/kg) & $461.10 \pm 6.45$ & $540.17 \pm 3.77$ & $* *$ \\
\hline Protein $(\mathrm{g} / \mathrm{kg})$ & $61.67 \pm 1.20$ & $84.00 \pm 1.15$ & $* *$ \\
\hline Fat $(\mathrm{g} / \mathrm{kg})$ & $75.33 \pm 3.18$ & $125.67 \pm 3.48$ & $* *$ \\
\hline Ash (g/kg) & $9.13 \pm 0.09$ & $12.50 \pm 0.12$ & $* *$ \\
\hline Carbohydrate (g/kg) & $314.97 \pm 4.53$ & $318.00 \pm 1.53$ & NS \\
\hline Acidity (\%) & $0.21 \pm 0.00$ & $0.19 \pm 0.003$ & $* *$ \\
\hline \multicolumn{4}{|l|}{ Microbiological } \\
\hline Total viable count (log cfu/g) & $3.84 \pm 0.05$ & $3.77 \pm 0.07$ & NS \\
\hline Coliform count. (log cfu/g) & Nil & Nil & - \\
\hline
\end{tabular}

${ }^{\text {NS }}$ Non significant $* *$ Significant at $1 \%$ level

\section{Microbiological quality}

\section{Total viable count}

The numbers of viable bacteria of $\mathrm{A}$ and $\mathrm{B}$ was $3.84 \pm 0.05$ and $3.77 \pm 0.07 \mathrm{log} \mathrm{cfu} / \mathrm{g}$, respectively and there was a non-significant $(\mathrm{P}>0.05)$ difference between them. So if the rasomalai prepared in a good sequence with good quality control practice, then it will be lower in bacterial content (Table 2).

\section{Coliform count}

It was found that coliform bacteria were absent in all types of rasomalai samples. Coliform bacteria are the indicators of hygienic conditions present during the manufacturing of the product. So, coliform count indicates that strict hygienic measures were taken during rasomalai preparation (Table 2).

\section{Economics of rasomalai production}

Three $\mathrm{kg}$ cow milk produced $1.15 \mathrm{~kg}$ rasomalai and $3 \mathrm{~kg}$ buffalo milk produced $1.40 \mathrm{~kg}$ rasomalai Market price of $1 \mathrm{~kg}$ rasomalai was Tk. 140.00 (2008). Price of $1.15 \mathrm{~kg}$ cow milk rasomalai is Tk. 161.00 and Price of $1.40 \mathrm{~kg}$ buffalo milk rasomalai is Tk. 196.00. Extra profit from $3 \mathrm{~kg}$ buffalo milk was Tk. (196-161) = Tk. 35.00. Because of higher yield of chhana and malai, buffalo milk produces more rasomalai than cow milk. So, preparation of rasomalai from buffalo milk is economically profitable.

\section{Conclusion}

Considering the quality parameter and economical statement, it may be concluded that rasomalai produced is profitable buffalo milk the cow milk. 
Bang. J. Anim. Sci. 2008, 37 (1)

\section{Literature Cited}

Alam, S. M. K. 1999. A comparative study on the quality of dahi (Yoghurt) prepared from cow, goat and buffalo milk, M.S. Thesis, Department of Dairy Science, Bangladesh Agricultural University, Mymensingh.

De, S. and Ray, S. C. 1954. Body and texture of rasogolla from buffalo milk. Indian J. Dairy Sci. $7: 143$.

FAO (Food and Agriculture Organization). 1997. FAO production Year Book Rome. Italy. $51: 218$.

Forth Plan Study No. 3. 1968. Estimation of livestock and poultry population and their products. Government of East Pakistan. Dept. Agril. Sec. p. 34.

Haque, M. A. 2000. A comparative study of rasogolla production from fresh cow milk, buffalo milk and mixture of cow and buffalo milk, M.S. Thesis, Department of Dairy Science, Bangladesh Agricultural University, Mymensingh

Islam, M. Z., Rahman, S. M. R., Alam, M. M. and Mannan, A. K. M. A. 2003. Manufacture of rasomalai and It's quality attributes: An indigenous milk sweetmeat of Bangladesh. Pakistan J. Nutri. 2 (5) : 300-304.

Jainudeen, M. R. 2003. Buffalo husbandry. Encyclopedia of Dairy Science. Academic Press and Imprint of Elsevier Science, San Diego, California, USA. 1 : 191-192.

Joshi, S. V., Majgaonkar, S. V. and Toro, V. A. 1991. Effect of different coagulants on yield and sensory quality of chhana prepared from milk of cow, buffalo and goat. Indian J. Dairy Sci. 44 (6) : 380-383.

Katra, R. V. and Bhargava, V. N. 1990. Production of rasogolla from cow milk containing different levels of soy milk. Asian J. Dairy Res. 9(4) : 175-180.

Kuila, R. K., Sen, D. C. and Misra, R. K. 2000. Milk sweet of Eastern India. Dairy development in Eastern India. $13: 64-73$.

Marsili, 2003. Flavours and off flavours in dairy foods. Encyclopedia of Dairy Science. Academic Press and Imprint of Elsevier Science, San Diego, California, USA. 2 : 1069-1081.

Mathur, B. N., Zanjad, P. N. and Rao, K. V. S. S. 1991. Paneer and Tofu: An appraisal of product and process synergies. Indian Dairyman. 47(91) : 407-413.

Rao, M. S., Rao, M. R., Ranganadham, M. and Rao, B. V. R. 1989. Study on the preparation of chhana from buffalo milk and its suitability for rasogolla manufacture. Indian J. Dairy Sci. 42(4) : 810-816.

Yasmin, S., Wadud, A., Islam, M. N. and Hasan, T. 2005. Study on the quality of the rasomalai manufactured in laboratory and sweetmeat shops of different districts of Bangladesh. J. Bangladesh Agril. Univ. 3(1) : 71-76. 